\title{
Estimating employment dynamics across occupations and sectors of industry
}

Citation for published version (APA):

Cörvers, F., \& Dupuy, A. (2009). Estimating employment dynamics across occupations and sectors of industry. METEOR, Maastricht University School of Business and Economics. METEOR Research Memorandum No. 046 https://doi.org/10.26481/umamet.2009046

Document status and date:

Published: 01/01/2009

DOI:

10.26481/umamet.2009046

Document Version:

Publisher's PDF, also known as Version of record

\section{Please check the document version of this publication:}

- A submitted manuscript is the version of the article upon submission and before peer-review. There can be important differences between the submitted version and the official published version of record.

People interested in the research are advised to contact the author for the final version of the publication, or visit the DOI to the publisher's website.

- The final author version and the galley proof are versions of the publication after peer review.

- The final published version features the final layout of the paper including the volume, issue and page numbers.

Link to publication

\footnotetext{
General rights rights.

- You may freely distribute the URL identifying the publication in the public portal. please follow below link for the End User Agreement:

www.umlib.nl/taverne-license

Take down policy

If you believe that this document breaches copyright please contact us at:

repository@maastrichtuniversity.nl

providing details and we will investigate your claim.
}

Copyright and moral rights for the publications made accessible in the public portal are retained by the authors and/or other copyright owners and it is a condition of accessing publications that users recognise and abide by the legal requirements associated with these

- Users may download and print one copy of any publication from the public portal for the purpose of private study or research.

- You may not further distribute the material or use it for any profit-making activity or commercial gain

If the publication is distributed under the terms of Article $25 \mathrm{fa}$ of the Dutch Copyright Act, indicated by the "Taverne" license above, 


\section{Maastricht University}

Frank Cörvers, Arnaud Dupuy

Estimating employment dynamics across occupations and sectors of industry

$\mathrm{RM} / 09 / 046$

\section{METEOR}

Maastricht University School of Business and Economics

Maastricht Research School of Economics

of Technology and Organization

\section{P.O. Box 616}

NL - 6200 MD Maastricht

The Netherlands 


\title{
Estimating employment dynamics across
}

\section{occupations and sectors of industry.*}

\author{
Frank Cörvers`and Arnaud Dupuy ${ }^{\ddagger}$
}

September 15, 2009

\begin{abstract}
In this paper, we estimate the demand for workers by sector and occupation using system dynamic OLS techniques to account for the employment dynamics dependence across occupations and sectors of industry. The short run dynamics are decomposed into intra and intersectoral dynamics. We find that employment by occupation and
\end{abstract}

${ }^{*}$ The authors would like to thank Erik de Regt, an anonymous referee and participants at the 2004 Applied Econometrics Association European Meetings, Econometrics of Labour Demand, in Mons and 2003 conference on "Modelling labour market: realities and prospects" in Athens for very helpful comments on earlier drafts of the paper.

${ }^{\dagger}$ Research Centre for Education and the Labour Market (ROA), Maastricht University, frank.corvers@maastrichtuniversity.nl.

${ }^{\ddagger}$ Corresponding author, a.dupuy@maastrichtuniversity.nl. Research Centre for Education and the Labour Market (ROA) and department of economics, Maastricht University. 
sector is significantly affected by the short run intersectoral dynamics, using Dutch data for the period 1988-2003. On average, these intersectoral dynamics account for $20 \%$ of the predicted occupational employment.

JEL classification: J21, J23

Key words: Labour demand, Occupational structure, Intra and Intersectoral dynamics, System Dynamic OLS. 


\section{Introduction}

While the causes and consequences of long run sectoral shifts observed in the last two centuries have been extensively documented in the literature, little is known about the short run employment dynamics between sectors. Similarly, the labor economics literature has extensively documented complementarities in production between various types of skills groups (Hamermesh, 1986, 1993) in the long run, whereas short run dependence across skills groups are surprisingly under documented.

Nevertheless, several examples suggest the importance of employment dynamics across occupations and sectors. For instance, consider what happens to employment in various sectors when exceptionally bad weather conditions or veterinary diseases ${ }^{1}$ suddenly affect production in the agricultural sector of industry. While it is obvious that employment in the agricultural sector will drop in the short run, employment in particular occupations in other (complementary) sectors, such as food processing occupations in the food industry and truck drivers in the transport industry, will also drop. What

\footnotetext{
${ }^{1}$ Think of the 2001 winter outbreak of the Foot-and-Mouth disease in Britain, and its eventual spread to continental Europe. To prevent further spread, 10 millions animals were destroyed in Great Britain only. Note that this massive undertaking has been performed by the British army.
} 
matters here is that a negative output shock in one sector is the source of contagion for falling labor demand in other sectors of industry.

Another example of the importance of short run complementarities is the interdependence of the building trade and banking industries. Imagine a sudden decrease in building activities, ${ }^{2}$ leading to a fall in labor demand for building trades such as brick layers, electricians, plumbers, drywallers and framers. It is most likely that the decline in building activities will in turn decrease the number of truck drivers in the transport industry, since materials have to be transported to building sites, as well as the number of finance jobs in the banking and insurance industry, since less mortgages will be sold. Also credit crises can be regarded as exogenous factors with large negative spill-over effects to sectors of industry in the real economy that are heavily dependent on the continuation of loans. One may think of sectors that have to make large capital investments such as the building or chemical industries. This implies that employment in the building or chemical industries may suddenly fall when these sectors are infected by shocks elsewhere in the economy. These negative employment effects may spread around other sectors of industry as well.

\footnotetext{
${ }^{2}$ For instance, Dutch building companies had to pay large penalties after 2000 for practicing fraud and cartel forming.
} 
Furthermore, a sector hit by a negative shock will have to reduce output. This results into a fall in employment of the occupations in that sector, and may at the same time increase employment in these occupations in other sectors of industry. For example, when output in the building trades suddenly shrinks, labor demand for electricians in the building trades may rapidly decline. However, due to falling wages of electricians this may lead to rising labor demand for electricians in other sectors. This implies that the occupational structure in one sector of industry is related to the occupational structure in another in the short run.

This paper is the first attempt to quantify the importance of short run employment dynamics across occupations and sectors of industry. To account for these dynamics, we estimate labor demand equations by sector and occupation using system dynamic OLS techniques. This technique allows us to estimate long run structural parameters of labor demand by occupation and sector of industry and deviations from this long run equilibrium. These deviations are referred to as short run dynamics.

To estimate employment dynamics across sectors and occupations we use data from the Labor Force Survey of the Netherlands in the period 19882003, distinguishing between 13 sectors of industry and 43 occupations. The 
employment series by sector and occupation have both a long and short run relationship with value added, capital stock and $R \& D$ stock at the sectoral level. The short run dynamics are further decomposed into intra- and intersectoral dynamics. The intrasectoral dynamics indicates that changes in the explanatory variables in a sector affect occupational employment in that sector whereas the intersectoral dynamics indicates that changes in the explanatory variables in a sector affect occupational employment in other sectors. Thus the intersectoral dynamics refers to the examples mentioned above on the cross relationships between sectors of industries and their respective occupational structures.

To our knowledge we are the first to allow for short run interdependences across occupations and sectors of industry. Our most important finding is that intersectoral dynamics account, on average, for $20 \%$ of the predicted occupational employment series. We also find large differences across industries in the importance of intersectoral dynamics. For example, the agricultural, the transport and the banking and insurance sectors of industry are deeply affected by intersectoral dynamics, whereas many manufacturing industries are barely affected by other sectors in the short run.

In this paper, the long run employment structure is modeled as in the ex- 
isting labor studies on skill-biased technological change, ${ }^{3}$ e.g. Berman, Bound and Griliches (1994), Berman, Bound and Machin (1998), Goldin and Katz (1998) and Machin and Van Reenen (1998). This early literature distinguished only two types of skills, an approach that seems to be at odds with recent results provided in Aguirregabiria and Alonso-Borrego (2001), Osburn, (2001), Maurin and Thesmar (2004), Goos and Manning (2007) and Dupuy and Marey (2008). These studies indeed show that the impact of factors like capital, technological change and scale of production on employment can be rather different and sometimes puzzling for the different types of required skills (e.g. cognitive versus non-cognitive) and tasks (e.g. routine versus non-routine) to be performed within various occupations. This occupationspecific behavior illustrates the relevance of distinguishing between different occupations when estimating the impact of production factors on employment. Our empirical approach distinguishes between 43 occupations in 13 sectors, and is therefore able to take into account the kind of heterogeneity

\footnotetext{
${ }^{3}$ The evidence for the market value of the skills associated to the new technologies and therefore evidence for the existence of new skills is questioned by some authors (see DiNardo and Pischke 1997). Other studies refer to the importance of the decentralization of organizations due to technological change, requiring more skilled workers than in the past (Bresnahan, Brynjolfsson, and Hitt, 2002; Caroli and Van Reenen, 2001), or emphasize that new technologies make it possible to allocate more workers from routine to nonroutine cognitive activities, for example for the conception and marketing of new products (Autor, Levy and Murnane 2003; Maurin and Thesmar, 2004; Goos and Manning, 2007).
} 
documented by the later literature.

The remaining structure of the paper is as follows. Section 2 discusses the data. Section 3 presents the multiple cointegrating model characterizing both the long run structure of occupational employment and the short run occupational employment dynamics. The two step System Dynamic OLS regression technique is used to estimate the parameters of the model. Section 4 presents the empirical results and an illustration. Section 5 concludes the paper.

\section{Data}

We use employment data on occupations and sectors of industry that has been drawn from the Labour Force Survey (LFS) of Statistics Netherlands. The Dutch LFS is a continuous sample survey research of all people residing in the Netherlands with the exception of residents in institutions, resident care hostels and homes. Each year some 100,000 questionnaires are completed. ${ }^{4}$ Every person between 15 and 64 years old carrying out at least 12

\footnotetext{
${ }^{4}$ The number of respondents between 15 and 64 years old was 112.000 in 1990 and 84.000 in 2003 . The sample design, the data collection and the weighting schemes used by Statistics Netherlands have changed slightly over time. However, the impact of these changes on the employment numbers and the sample variance seems to be limited. See Lemaître and Dufour (1987), Renssen (1998) and CBS (1991, 2004) for more details.
} 
hours paid work per week are allocated to the working population. ${ }^{5}$ In this paper, we cover the whole spectrum of occupations and sectors of industry of the labour market in the Netherlands. The total number of workers in the Netherlands was 5.4 million in 1988 and 7.1 million in 2003.

We distinguish between 13 sectors of industry. Moreover, we constructed a time series of occupational employment by industry for the period between 1988 and 2003. We distinguish between 43 occupational classes. The classifications used are based on the classifications of Statistics Netherlands, and are shown in the Appendix. In this paper occupational employment is estimated for 195 combinations of industry and occupation. In the remaining combinations too few workers were employed to construct reliable time series. This concerns about $6 \%$ of the total number of workers.

During the period under consideration there were some changes in the classifications by sector and occupation. The problems caused by these changes have been largely solved by using concordance tables provided by Statistics Netherlands, and by comparing the numbers of employed persons according to the old and new classifications for particular years of obser-

\footnotetext{
${ }^{5}$ In the Netherlands the classification of one's labour market status (employed, unemployed or inactive) depends on the number of hours one wants to work. People who work or are willing to work for less than 12 hours a week are classified as inactive.
} 
vation. ${ }^{6}$ Moreover, sample variance of the number of employed persons in each occupation-sector category in the LFS is rather high, especially for occupation-sector categories with few workers, as indicated by the occasional picks in Figure 1 and Figure 2. In 2003, Statistics Netherlands estimated the 95\%-confidence intervals to be $+/-31.3 \%$ and $12.8 \%$ at the level of 5.000 and 30.000 workers (weighted), respectively. In 1990, the estimated confidence intervals were $+/-30.1 \%$ and $12.3 \%$. The rather large confidence intervals will lead to biased estimates of the demand equations for each individual occupation-sector category. To reduce the bias due to sampling variability, we estimate the demand equations simultaneously and restrict the slope parameters to vary across sectors and occupations but without interaction, and control for occupation and industry fixed effects and year fixed effects. Hence, this method treats occasional picks in occupation-sector categories as containing economic information only when these picks also appear simultaneously in either other occupations within the same sector or in the same occupation but in another sector. If not, these picks will be treated as random shocks. For instance in Figure 1 and Figure 2, the predicted series do not follow the occasional picks observed in the occupational series, as these

\footnotetext{
${ }^{6}$ For instance, in 1994, the numbers of employed persons are available for both the old and the new sector classifications.
} 
picks only occurred in the respective series.

The industrial data on value added and capital investments (both machinery and structures) are based on the National Accounts of Statistics Netherlands. These time series have a break from 1994 to 1995 due to the introduction of a new system of national accounts. Time series on investments in research and development (definition according to the Frascati Manual of the OECD) are published by Statistics Netherlands. These data are mainly based on R\&D and innovation surveys among businesses, research institutes and universities. The industrial data can be downloaded from the website of Statistics Netherlands (www.cbs.nl).

To calculate stocks of capital and R\&D we applied the widely used Perpetual Inventory Method (PIM). Time series of investments in capital and R\&D are used for the period of $1970-2003$, with a depreciation rate of 0.08 and 0.15 respectively. The initial stock of capital and $R \& D$ is calculated as the value of investment in the first year divided by the deprecation rate plus the growth rate of investment in the first three years of the time series.

Tables 1 and 2 present summary statistics by sectors for our 195 employment series by occupation and sector and 13 sectoral series of capital stock, R\&D stock and value added. 


\section{Econometric model}

Consider the following economic model of occupational employment within sectors:

$$
\begin{aligned}
l_{i j t} & =\alpha_{i j}+\beta_{i j} t+\underline{x}_{i t}^{\prime} \underline{\delta}_{i j}+\varepsilon_{i j t} \\
\Delta \underline{x}_{i t} & =\underline{\xi}_{i t} \\
\underline{\xi}_{i t} & =\sum_{o s} \underline{\gamma}_{o s}^{i} \varepsilon_{o s t-1}+\sum_{s} \Gamma_{s}^{i} \underline{\xi}_{s t-1} \\
\varepsilon_{i j t} & =\sum_{o s} \eta_{o s}^{i j} \varepsilon_{o s t-1}+\sum_{s} \underline{\xi}_{s t-1}^{\prime} \underline{\theta}_{s}^{i j}
\end{aligned}
$$

where $l_{i j t}$ is $\log$ employment in occupation $j$ in sector $i, \underline{x}_{i t}$ is a $3 \times 1$ vector of explanatory variables for sector $i$, i.e. $\log$ capital, $\log \mathrm{R} \& \mathrm{D}$ and $\log$ value added. $\varepsilon_{i j t}$ is an error term for occupation j in sector i. $\underline{\xi}_{i t}$ is a $3 \times 1$ vector of errors. The long run parameters are a constant $\alpha_{i j}$, a trend $\beta_{i j}$, and a $3 \times 1$ vector of coefficients $\underline{\delta}_{i j}$ relating long run employment to sector capital stock, R\&D stock and value added. The short run parameters are $\underline{\gamma}_{o s}^{i}$ for all $o, s$ and $i$ and $\underline{\theta}_{s}^{i j}$ for all $s, j$ and $i, 3 \times 1$ vectors of parameters specific to each combination of occupation and sector, $\eta_{o s}^{i j}$ for all $o, s, i$ and $j$, a constant specific to each occupation sector combination and $\Gamma_{s}^{i}$ for all $i$ and $s$, which 
is a $3 \times 3$ matrix of parameters specific to each sector.

Equation 1 depicts the long run employment structure of the economy whereas equations 2, 3 and 4 depict the short term dynamics. This model is known in the econometric literature as a multiple cointegrating model (see e.g. Stock and Watson, 1993 and Mark et al. 2005). In this model, $l_{i j t}$ and $x_{i j t}$ are stochastic processes both integrated of order 1 , with cointegrating vectors $\underline{\delta}_{i j}$ specific to each combination of occupation and sector.

Two features of this model are important to note. First, as long as $\underline{\gamma}_{o s}^{i}$ and $\underline{\theta}_{s}^{i j}$ are different from $\underline{0}$ for some $i$ and $j$, where $\underline{0}$ is a $3 \times 1$ vector of zeros, the errors $\varepsilon_{i j t}$ are correlated with $\underline{\xi}_{i t}$, i.e. the current changes in the regressors $\underline{x}_{i t}$. The intuition is that the same unobserved (to the econometrician) factors influence firms' employment decisions in occupation $j$ and sector $i$ at $t-1$ and firms' decisions to increase the stock of capital, the stock of R\&D or economic activity in general (value added) between period $t$ and $t-1 .^{7}$ This means that the usual exogeneity assumptions of $\underline{x}_{i t}$, required for the consistency of OLS regressions, does not hold and OLS estimates will be biased (see Griliches and Mairesse, 1995).

\footnotetext{
${ }^{7}$ A classical example of such a factor is weather in the agricultural sector (see e.g. Varian, 1984).
} 
Second, the short run structure of the model exhibits dynamic dependency across occupations and sectors. As long as $\eta_{o s}^{i j} \neq 0$, employment at time $t$ in occupation $j$ in sector $i$ depends on past employment in occupation $o$ and sector $s$. This means that employment shocks in occupation $o$ in sector $s$ in the previous period affect current employment in occupation $j$ in sector $i$. Similarly, as long as $\underline{\theta}_{s}^{i j} \neq \underline{0}$, past shocks in capital stock, R\&D stock or value added in sector $s$ affect current employment in occupation $j$ in sector $i$. Also, as long as $\underline{\gamma}_{o s}^{i} \neq \underline{0}$, past shocks in employment in occupation $o$ in sector $s$ affect changes in the stock of capital, the stock of R\&D and the value added in sector $i$ and as long as $\Gamma_{s}^{i}$ is not diagonal, past changes in the stock of capital, the stock of R\&D and value added in sector $s$ affect the current changes in the stock of capital, the stock of $R \& D$ and value added in sector $i$.

Our data has yet two shortcomings. First, the rather small length of the time series requires to estimate the parameters of the model with few degrees of freedom. Second, the data has a rather large sample variance, especially for small occupation-sector combinations. Hence, to gain efficiency and achieve more robust estimates we restrict the slope parameters to vary across sectors and occupations but without interaction, while controlling for 
occupation $\times$ industry fixed effects and year fixed effects. This means that occasional picks in occupation $\times$ sector combinations are treated as containing economic information if and only if these picks also appear simultaneously in either other occupations within the same sector or in the same occupation but in another sector. If not, these picks will be treated as random shocks. The restricted model reads as:

$$
\begin{aligned}
l_{i j t} & =\alpha_{i j}+\beta_{t}+\underline{x}_{i t}^{\prime}\left(\underline{\delta}_{i}+\underline{\delta}_{j}\right)+\varepsilon_{i j t} \\
\Delta \underline{x}_{i t} & =\underline{\xi}_{i t} \\
\underline{\xi}_{i t} & =\sum_{o s} \underline{\gamma}_{o s}^{i} \varepsilon_{o s t-1}+\sum_{s} \Gamma_{s}^{i} \underline{\xi}_{s t-1} \\
\varepsilon_{i j t} & =\sum_{o s} \eta_{o s}^{i j} \varepsilon_{o s t-1}+\sum_{s} \underline{\xi}_{s t-1}^{\prime} \underline{\theta}_{s}^{i j}
\end{aligned}
$$

We estimate the restricted model defined by equations $5-8$ using System Dynamic OLS (or SDOLS) regression techniques and in particular implement the two-step procedure proposed by Mark et al. (2005). In the first step, we purge for the endogeneity problem caused by equations 7 and 8 by regressing i) $l_{i j t}$ onto $\Delta \underline{x}_{i t}$ to get $\widehat{l_{i j t}}=a_{i j}+b_{t}+\Delta \underline{x}_{i t}^{\prime}\left(\underline{c}_{i}+\underline{c}_{j}\right)$ for occupation $j$ in sector $i$ and ii) regress each of the explanatory variables $x_{i t}^{k}$ onto the change 
in all explanatory variables of all sectors, i.e. $\left(\Delta \underline{x}_{1 t}, \ldots, \Delta \underline{x}_{S t}\right)$. This last regression allows us to take into account the fact that changes in the stock of capital, the stock of $\mathrm{R} \& \mathrm{D}$ and value added in one sector will generally contaminate the stock of capital, the stock of $R \& D$ and value added in other sectors. Therefore, for each explanatory variable $k$ in sector $i$ at time $t$ we have $\widehat{x}_{i t}^{k \prime}=d_{i}^{k}+\sum_{s=1}^{S} \Delta \underline{x}_{s t}^{\prime} \underline{e}_{s}^{i, k}$. Stacking over $k$ yields $\underline{\widehat{x}}_{i t}=\underline{d}_{i}+\underline{\sum}_{s=1}^{S} \Delta \underline{x}_{s t}^{\prime} \underline{e}_{s}^{i}$.

In the second step, we regress the errors $l_{i j t}-\widehat{l}_{i j t}$ of regression i) from the first step onto the errors $\underline{x}_{i t}-\underline{\widehat{x}}_{i t}$ of regressions ii) of the first step, that is:

$$
l_{i j t}-\widehat{l}_{i j t}=g_{i j}+\left(\underline{x}_{i t}-\underline{\widehat{x}}_{i t}\right)^{\prime}\left(\underline{h}_{i}+\underline{h}_{j}\right)+\nu_{i j t}
$$

where $\nu$ is a white noise.

Note that substituting $\widehat{l}_{i j t}$ and $\underline{\widehat{x}}_{i t}$ by their expressions in terms of the estimated coefficients and rearranging yields: 


$$
\begin{aligned}
l_{i j t}= & \underbrace{a_{i j}+g_{i j}+\underline{d}_{i}^{\prime} \underline{h}_{j}+\underline{d}_{i}^{\prime} \underline{h}_{i}}+b_{t}+\underline{x}_{i t}^{\prime}\left(\underline{h}_{i}+\underline{h}_{j}\right) \\
& +\underbrace{\Delta \underline{x}_{i t}^{\prime}\left(\underline{c}_{i}+\underline{c}_{j}+\underline{e}_{i}^{i \prime}\left(\underline{h}_{i}+\underline{h}_{j}\right)\right)}+\underbrace{\left(\sum_{s \neq i} \Delta \underline{x}_{s t}^{\prime} \underline{e}_{s}^{i}\right)^{\prime}\left(\underline{h}_{i}+\underline{h}_{j}\right)}+\nu_{i j t}
\end{aligned}
$$

The estimate of the long run parameters of the model appear clearly on the first row of equation 10 . The term $a_{i j}+g_{i j}+\underline{d}_{i}^{\prime} \underline{h}_{j}+\underline{d}_{i}^{\prime} \underline{h}_{i}$ is the estimate of $\alpha_{i j}$, the occupation $\times$ sector fixed effects, $b_{t}$ is the estimate of $\beta_{t}$, the year fixed effect, $\underline{h}_{i}$ is the estimate of $\underline{\delta}_{i}$, the sector specific long run slope, $\underline{h}_{j}$ is the estimate of $\underline{\delta}_{j}$, the long run occupation specific slope. The second row of equation 10 contains the parameters associated with the short run dynamic of the model. This part of the model should be seen as a reduced form of equation $6-8$. The first term captures the dynamic relationship between the level of employment in occupation $j$ in sector $i$ at time $t$ and changes in the explanatory variables in that sector. This term therefore sizes the intersectoral effect of changes in the explanatory variables on employment. The term $\left(\underline{c}_{i}+\underline{c}_{j}+\underline{e}_{i}^{i \prime}\left(\underline{h}_{i}+\underline{h}_{j}\right)\right)$ is a reduced form estimate of parameters $\underline{\gamma}_{i j}^{i}$, $\Gamma_{i}^{i}, \eta_{i j}^{i j}$ and $\underline{\theta}_{i j}^{i}$ and has a sector specific component $\underline{c}_{i}+\underline{e}_{i}^{i \prime} \underline{h}_{i}$, an occupation 
specific component, $\underline{c}_{j}$ as well as an interaction between sector and occupation component $\underline{e}_{i}^{i \prime} \underline{h}_{j}$.

The second term captures the dynamic relationship between the level of employment in occupation $j$ in sector $i$ at time $t$ and changes in the explanatory variables in all other sectors. This term therefore sizes the intersectoral effect. The term $\underline{e}_{s}^{i \prime}\left(\underline{h_{i}}+\underline{h_{j}}\right)$ is a reduced form estimate of parameters $\underline{\gamma}_{o s}^{i}$, $\Gamma_{s}^{i}, \eta_{o s}^{i j}$ and $\underline{\theta}_{s}^{i j}$ for all $s \neq i$ and all $o \neq j$ for all $i$ and $j$, and has a sector specific component $\underline{e}_{s}^{i \prime} \underline{h_{i}}$ and an interaction between sector and occupation component $\underline{e}_{s}^{i \prime} \underline{h}_{j}$.

\section{Results}

\subsection{Cointegration tests}

In the model depicted by equations $1-4, l_{i j t}$ and $x_{i t}$ are assumed to be $I(1)$ processes. We test whether this is the case in our data. As indicated in Table 3, the Augmented Dickey-Fuller (ADF) test statistics (with drift) are not significant for most time series at hand, that is the log employment by occupation and sector as well as the explanatory variables by sector. The empirical testing reveals that all time series on $R \& D$, capital and value added 
are integrated of order 1. For the employment series by occupation and sector, 172 out of the 195 series are integrated of order 1.

$<$ insert Table $3>$

The model also assumes that $l_{i j t}$ and $x_{i t}$ are cointegrated with cointegrating vectors $\underline{\delta}_{i j}$. For each combination of occupation and sector, we proceed to a $\mathrm{ADF}$ test of cointegration in the long run relationship (equation 1) separately. The results, reported in Table 3, indicate that for 185 out of 195 (95\%) occupation-sector combinations, the deviations of the employment series from their long run paths are stationary. The model depicted in section 3 is therefore particularly suited for the data at our disposal.

\subsection{SDOLS parameter estimates}

\subsubsection{Main results}

Since the aim of the paper is to document the importance of short run dynamics in occupational employment within sectors, we proceed and test the significance of the short-run dynamics parameters $\underline{c}_{i}, \underline{c}_{j}$ and $\underline{e}_{i}^{s}$ for all $i, j$ and $s$. We first test, by means of a F-test, whether the vector of sector-specific parameters $\underline{c}_{i}$ is significantly different from $\underline{0}$. This means that we test whether changes in value added, capital and $\mathrm{R} \& \mathrm{D}$ between $t$ and $t-1$ in sector $i$ 
affect significantly employment level in all occupations of sector $i$ at time $t$. The F-test statistic for this test is 17.9 and significant at $1 \%$. Second, we test whether the vector of occupation-specific parameters $\underline{c}_{j}$ is significantly different from $\underline{0}$. In other words, this means that we test whether changes in value added, capital and $\mathrm{R} \& \mathrm{D}$ between $t$ and $t-1$ in sector $i$ affect employment level in occupation $j$ in all sectors at time $t$. The F-test statistic for this test is 2.8 which is also significant at $1 \%$. Third, we test whether the vector of sector-specific parameters $\underline{e}_{s}^{i}$ is significantly different from $\underline{0}$, that is whether employment in all occupations of sector $i$ at time $t$ is significantly affected by changes in value-added, capital stock and $\mathrm{R} \& \mathrm{D}$ between $t-1$ and $t$ in other sectors, $s$. The test-statistics are equal to 434.1, 229.2 and 308.45 for value-added, capital stock and $\mathrm{R} \& \mathrm{D}$ respectively and are all significant at the $1 \%$ level. Test 1 and 2 refer to the intrasector dynamics while test 3 refers to the intersector dynamics. The results indicate thus that both the intra and inter sector dynamics are important determinants of the occupational employment within sectors.

To size the share of the intersectoral dynamics in explaining occupational employment within sectors, we first derive the ex post prediction of the occupational employment within sectors using the full model as depicted in 
equation 10 and then derive the ex post prediction while shutting down the intersectoral dynamics, i.e. setting $\left(\underline{\sum_{s \neq i} \Delta \underline{x}_{s t}^{\prime} \underline{e}_{s}^{i}}\right)^{\prime}\left(\underline{h}_{i}+\underline{h}_{j}\right)=0$. This allows us to derive the share of our model's prediction due to intersectoral dynamics. These shares are reported in Table 5. On average, the intersectoral dynamics account for $20 \%$ of our predicted occupational employment series. Although, large variations are observed across sectors. While our predicted employment series in the Metal industry, Paper, plastic rubber and other industries, Energy, Building trade and Hotel and catering are merely due to intrasectoral dynamics (share of intersectoral dynamics is less than 10\%), our predicted occupational employment series in the Agricultural, Chemical, Transport, Banking and insurance and Governance and education sectors are to a large extent affected by intersectoral dynamics, $61 \%, 36 \%, 30 \%, 25 \%$ and $34 \%$ respectively.

The question arises why some sectors are more sensitive to shocks occuring elsewhere in the economy than others. At this stage, the answer to this question can only be speculative as we are not aware of microeconomic models dealing with this issue. Intuitively, one might argue that the transmission of shocks from sector to sector runs naturally in an economy where sectors of industry do not operate in complete isolation from other domestic sectors 
and/or from international trade. As long as part of a sector's output is used as input in other sectors' production process, a transmission mechanism from sector to sector exists. In this view, differences across sectors in the share of intersectoral dynamics could reflect differences in the extent to which a sector's input relies on the output of other sectors. Complementary to this explanation, production in some sectors may depend more heavily on import and export and hence on shocks in the world economy than in other industries in the Netherlands. The Netherlands is a very open economy (in 2008 total exports/GDP was almost 80\%), which is in particular due to the Dutch manufacturing industries. This might explain why the figures in Table 5 indicate that employment in most manufacturing industries is not so much affected by shocks in other Dutch industries.

It is also important to note that our results do not rule out the possibility that manufacturing industries are the source of contagion of shocks in other industries. Dutch manufacturing industries may affect other industries to which intermediate outputs are delivered, like the agricultural, chemical and transport industries. Also the banking sector may be affected, since it provides loans for investments in heavy equipment by manufacturing sectors. Finally, if the economy turns down due to falling exports and production by 
the manufacturing sectors, this may lead to decreasing tax income and eventually budget cuts by the government. So employment in the government sector may also suffer from fluctuations in the business sector.

\subsubsection{Additional results}

The long run structural parameters of the model characterizing the occupational structure within sectors are reported in Table 4 . We interpret these parameters as the reduced from expression of a production function at the sector level. Within sectors, optimal labor demand in each occupation depends on output level, the stock of capital and the stock of R\&D. The $\underline{h}_{i}$ and $\underline{h}_{j}$ parameters then reflect the elasticity of employment by sector and occupation with respect to the stock of capital, the stock of $R \& D$ and value added in that sector.

The first block of parameters refers to the sector specific elasticities, i.e. $\underline{h}_{i}$. For each explanatory variable, the F-statistics reported in Table 4 indicate that these elasticities are block-significant. The elasticity with respect to value added is the largest in the building industry ${ }^{8} 0.8+3.6=4.4$ (significant at $5 \%$ ) and the smallest in Governance and education, $-3.9+0.8=-3.1$.

\footnotetext{
${ }^{8}$ The coefficients are relative to the reference sector $\times$ occupation, i.e. unskilled occupation in the Agricultural sector.
} 
At first sight, negative elasticities with respect to value added might appear counterintuitive. However, they might arise for two reasons. First, negative elasticities with respect to value added might indicate that the production function at the sector level is non-homothetic so that, holding input prices constant, at each output level a different mix of inputs (labor, capital and $\mathrm{R} \& \mathrm{D})$ is optimal. Intuitively, think of higher isoquants as being more convex, meaning that substitution between inputs on higher isoquants is more difficult. Then, at constant relative prices, increases in output level may be achieved with a decrease in some inputs depending on technology. This means that output expansion in the Governance and Education sector for instance, could lead to increases in the stock of capital and/or R\&D at the expense of employment. Although theoretically possible, it is unlikely that output expansion would be met with cuts in employment in practice. A more probable explanation for negative elasticities with respect to value added is that this elasticity in fact reflects an elasticity with respect to wages since wages are part of value added. In an attempt to test this possibility, we used wage sum data at the sector level. Unfortunately, wage sum is highly correlated with value added. Including wage sum in the model causes multicollinearity problems and therefore does not help interpreting the sign of the 
parameters. For this reason we interpret the elasticity with respect to value added as the combined effects of demand shifts due to changes in the output level and changes in relative wages.

In contrast, the employment elasticity with respect to capital is the largest in Governance and education 6.6 (significant at 1\%) and the smallest in Agricultural sector -2.5 (significant at $5 \%$ ). This means that labor and capital are strong complements in production in the Governance and education sector with labor increasing by $6.6 \%$ when capital stock is increased by $1 \%$ and strong substitutes in the Agricultural sector as labor input decreases by $2.5 \%$ when capital stock raises by $1 \%$. The elasticity with respect to $R \& D$ is the largest in the trade sector, 0.5 (not significant) and the smallest in the Paper, plastic, rubber and other industries, -1.6 (significant at 1\%). Labor and R\&D appear to be substitutes in the Paper, plastic, rubber and other industries with labor decreasing by $1.6 \%$ as $\mathrm{R} \& \mathrm{D}$ stock increases by $1 \%$.

The second block of parameters presented in Table 4 refers to those occupation-specific elasticity parameters, i.e. $\underline{h}_{j}$, that are significant at $1 \%$. However, we also report the number occupations for which the elasticity parameter is significant at $5 \%$ for each of the three explanatory variables. It is interesting to note that employment in high-skill occupations, in general, 
has a negative and significant elasticity with respect to value added but a large and significant elasticity with respect to $R \& D$. Output expansion in a sector leads to a decrease in employment in high-skill occupations within that sector. However, this effect can be partly or fully compensated by the complementarity of high-skilled workers with new technology as indicated by the positive elasticities of employment in high-skill occupations with respect to $R \& D$. Another interesting result to note is that in particular the intermediate-skill occupations have a positive and significant elasticity with respect to capital, indicating labor-capital complementarity in production.

\subsection{Illustration}

We illustrate our main results by presenting the changes in employment for the high-skill professional technical occupation in two sectors, namely the Chemical and Transport sectors. Figures 1 and 2 show the actual and predicted employment series of this occupational class in the Chemical and Transport sector respectively. We distinguish between employment predictions with and without intersectoral dynamics. The difference between both predictions indicates the contribution of intersectoral dynamics conditional on the contribution of intrasectoral dynamics. This contribution is virtually 
insignificant when intra and intersectoral predictions are highly correlated and explain the same share of the employment dynamics.

As shown in Figure 1, for high-skill professional technical occupations in the Chemical industry there is no clear advantage of including intersectoral dynamics in the prediction of employment. This is confirmed by the large correlation between the employment predictions with and without intersectoral dynamics, i.e. 0.87. In contrast, as shown in Figure 2, for the high-skill professional occupation in the Transport sector, the intersectoral dynamics seems to be very important in the prediction of employment. In fact, they account for more than $85 \%$ of the full model predictions. Moreover, the correlation between both the full model predictions and the predictions without intersectoral dynamics is rather low, i.e. 0.37. Therefore, including intersectoral dynamics in the estimation model improves significantly the employment prediction for the high-skill professional technical occupations.

\section{Conclusion}

In this paper, we estimate both the long and short run relationships between sectoral and occupational employment, and value added, capital stock and 
R\&D stock at the sectoral level, using Dutch data for the period 1988-2003. Applying system dynamic OLS techniques allows us to decompose the short run dynamics into intra- and intersectoral dynamics.

The main contribution of this paper is that we find significant short run intersectoral dynamics indicating the relevance of cross relationships between sectors of industries and their respective occupational structures in the short run. Our most important finding is that these intersectoral dynamics account, on average, for $20 \%$ of the predicted occupational employment series. We also find large differences across industries in the importance of intersectoral dynamics. For example, the agricultural, the transport and the banking and insurance sectors of industry are deeply affected by intersectoral dynamics $(61 \%, 30 \%$ and $25 \%$ respectively of the employment variation explained is caused by intersectoral dynamics), whereas many manufacturing industries are barely affected by other sectors in the short run.

Our results imply that previous empirical studies on labor demand have suffered from not modeling important cross relationships in employment dynamics across industries and occupations. These dynamics may spread around the whole economy and labor market. This paper casts light on the importance of this "contagion" mechanism and speculates on how changes 
in occupational employment in one sector of industry can be transmitted to other sectors of industries. However, this paper leaves at least two important questions about the short run intersectoral dynamics for future research. First: are the results found for the Netherlands similar in other developed countries? While our results highlight the importance of intersectoral employment dynamics in the Netherlands, more research is needed to reveal how important intersectoral effects are for the labor markets of other countries. We have indeed argued that short run intersectoral dynamics can be important as long as sectors do not operate in complete isolation from other domestic sectors and/or from international trade and use other sectors' (domestic or not) output in their production processs. This would mean that other economies, where the share of other sectors' output in the production process are more (less) important, may exhibit different patterns of intersectoral dynamics.

Second, can we design policy interventions to prevent negative shocks to propagate from sector to sector? Our quantitative method provides results about the reduced form of the intersectoral employment dynamics. Future research should focus on developing a model describing the process by which shocks spill over from sector to sector. A particularly interesting line of 
research for policy makers would be to develop a methodology enabling us to identify by which sector(s) each sector is mainly affected in the short run, i.e. identify the source of these shocks in each sector. While our approach allows us to quantify the extent to which a sector is affected by shocks in other sectors, it is silent about the identity of the sectors responsible for the short run dynamics.

\section{References}

Aguirregabiria, V., and C. Alonso-Borrego (2001): "Occupational structure, technological innovation, and reorganization of production," Labour Economics, 8(1), 43-73.

Autor, D., F. Levy, and R. Murnane (2003): "The Skill Content of Recent Technological Change: An Empirical Exploration," Quarterly Journal of Economics, 118(4).

Berman, E., J. Bound, and Z. Griliches (1994): "Changes in the Demand for Skilled Labor Within US Manufacturing: Evidence from Annual Survey of Manufactures," Quarterly Journal of Economics, 109(1), 367-97. 
Berman, E., J. Bound, And S. Machin (1998): "Implications of SkillBiased Technological Change: International Evidence," Quarterly Journal of Economics, 113(4), 1245-79.

Bresnahan, T., E. Brynjolfsson, and L. Hitt (2002): "Information Technology, Workplace Organization, and the Demand for Skilled Labor: Firm-Level Evidence," Quarterly Journal of Economics, 117(1), 339-76.

Caroli, E., and J. V. Reenen (2001): "Skill-Biased Organizational Change? Evidence From A Panel Of British And French Establishments," The Quarterly Journal of Economics, 116(4), 1449-1492.

CBS (1991): "Enquête Beroepsbevolking 1990," Statistics Netherlands.

— (2004): "Enquête Beroepsbevolking 2003," Statistics Netherlands.

DiNardo, J., And J.-S. Pischke (1997): "The Return to Computer Use Revisited: Have Pencils Changed the Wage Structure Too?," Quarterky Journal of Economics, 112(1), 291-303.

Dupuy, A., And P. Marey (2009): "Shifts and Twists in the Relative Productivity of Skilled Labor," Journal of Macroeconomics, 30, 718-735. 
Goldin, C., And L. F. Katz (1998): "The Origins Of Technology-Skill Complementarity," The Quarterly Journal of Economics, 113(3), 693-732. Goos, M., And A. Manning (2007): "Lousy and Lovely Jobs: The Rising Polarization of Work in Britain," The Review of Economics and Statistics, 89(1), 118-133.

Griliches, Z., And J. Mairesse (1995): "Production Functions: The Search for Identification," NBER working paper series, No. 5067.

Hamermesh, D. (1986): "The Demand for Labor in the Long Run.," in Handbook of Labor Economics., ed. by O. Ashenfelter, and R. Layard, pp. 429-71. Amsterdam: North-Holland.

(1993): Labor Demand. Princeton, New Jersey: Princeton University Press.

Lemaître, G., And J. Dufour (1987): “An Integrated Method for Weighting Persons and Families," Survey Methodology, 13, 199-207.

Machin, S., and J. Van Reenen (1998): "Technology and Changes in Skill Structure: Evidence from Seven OECD Countries," Quarterly Journal of Economics, 113(4), 1215-44. 
Mark, N. C., M. Ogaki, and D. Sul (2005): "Dynamic Seemingly Unrelated Cointegrating Regressions," Review of Economic Studies, 72(3), $797-820$.

Maurin, E., And D. Thesmar (2004): "Changes in the Functional Structure of Firms and the Demand for Skill," Journal of Labor Economics, $22(3), 525-552$.

Osburn, J. (2001): "Occupational Upgrading and Changes in Capital Usage in U.S. Manufacturing Industries," Review of Income and Wealth, 47(4), $451-72$.

Renssen, R. (1998): "A Course in Sampling Theory," Statistics Netherlands, BPA no. 2138-98-RSM-1.

Stock, J. H., And M. W. Watson (1993): "A Simple Estimator of Cointegrating Vectors in Higher Order Integrated Systems," Econometrica, 61(4), $783-820$.

VARIAn, H. (1984): Microeconomic Analysis. New York: Norton and Company, 2nd edn. 


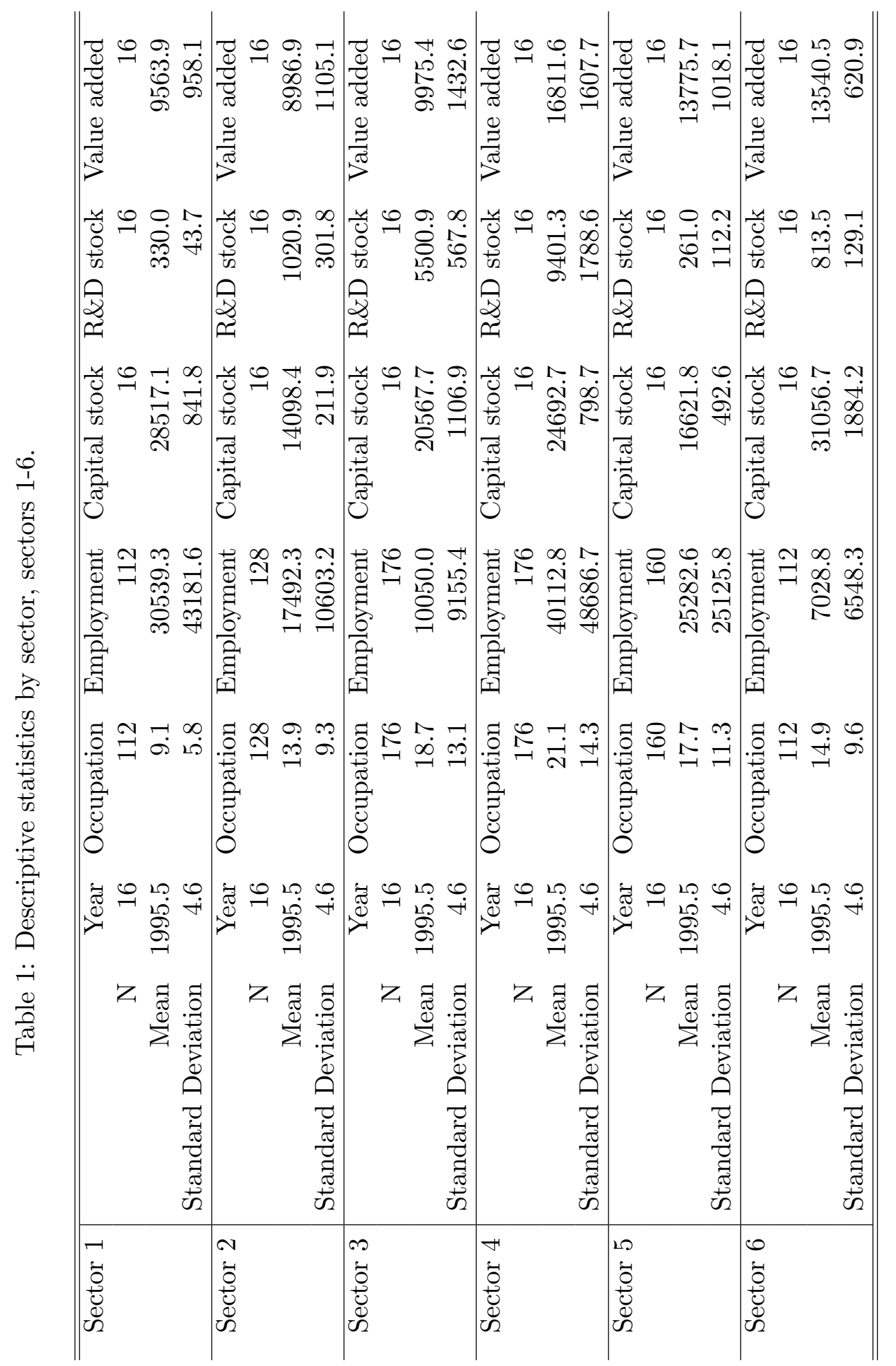




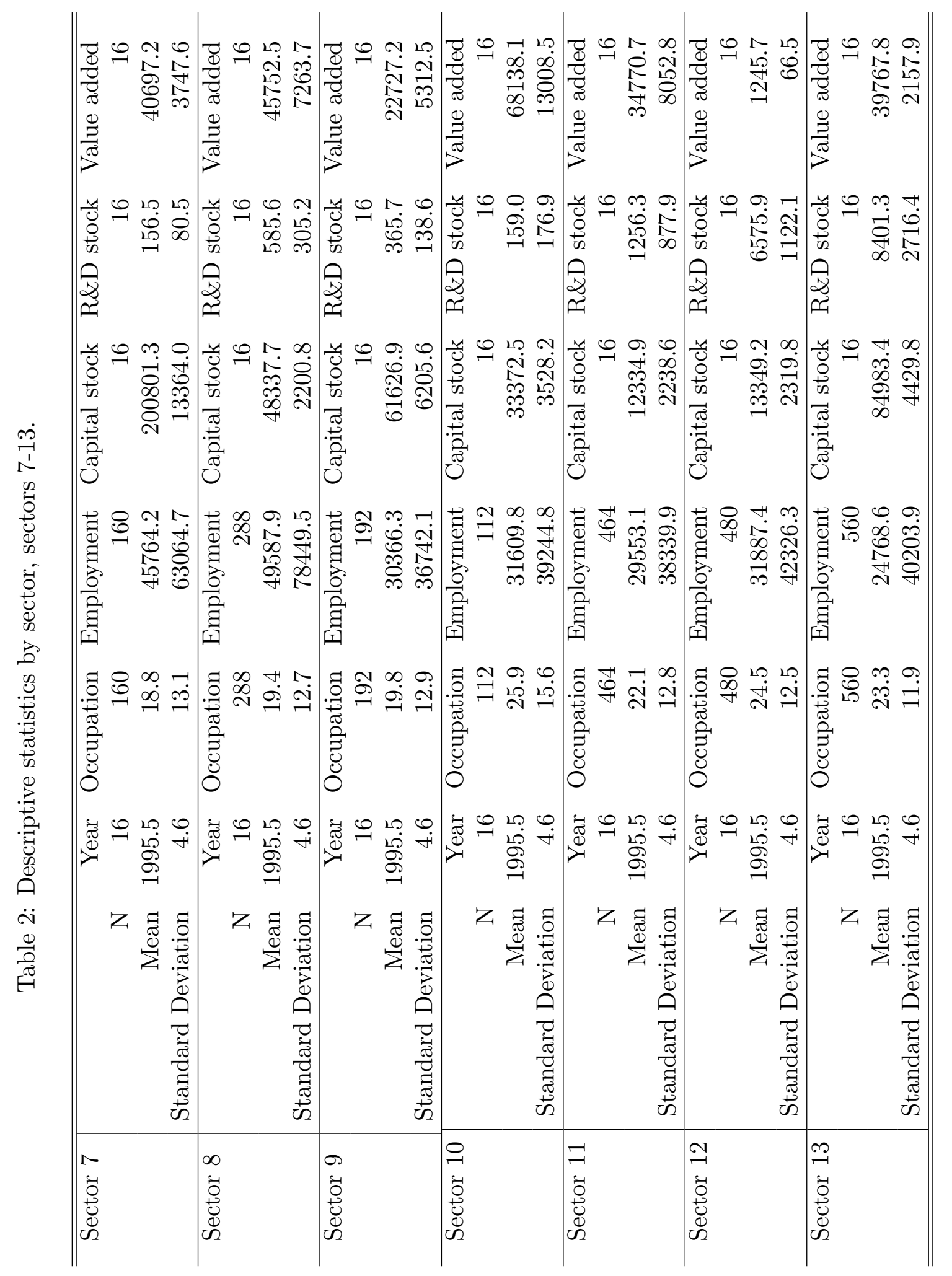




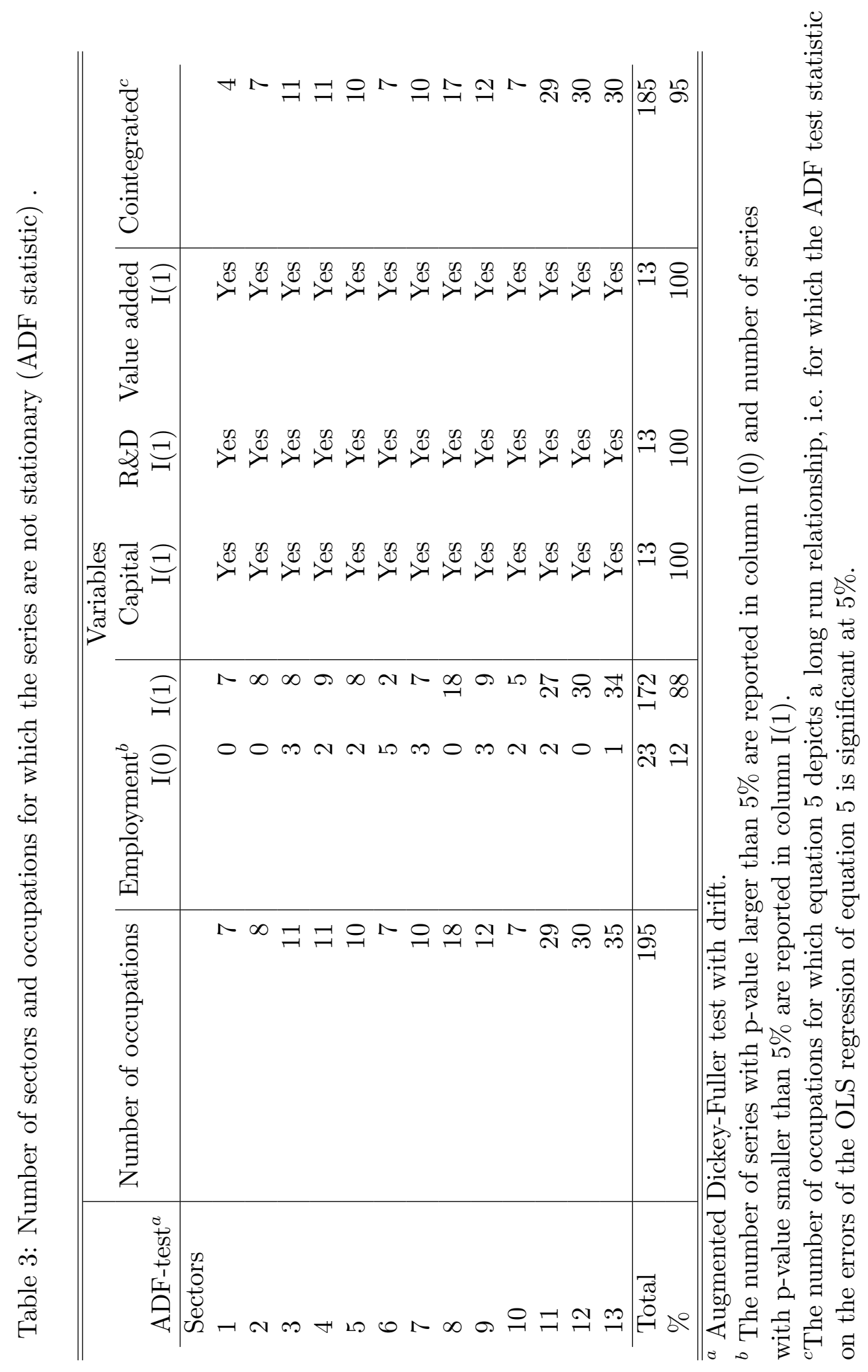




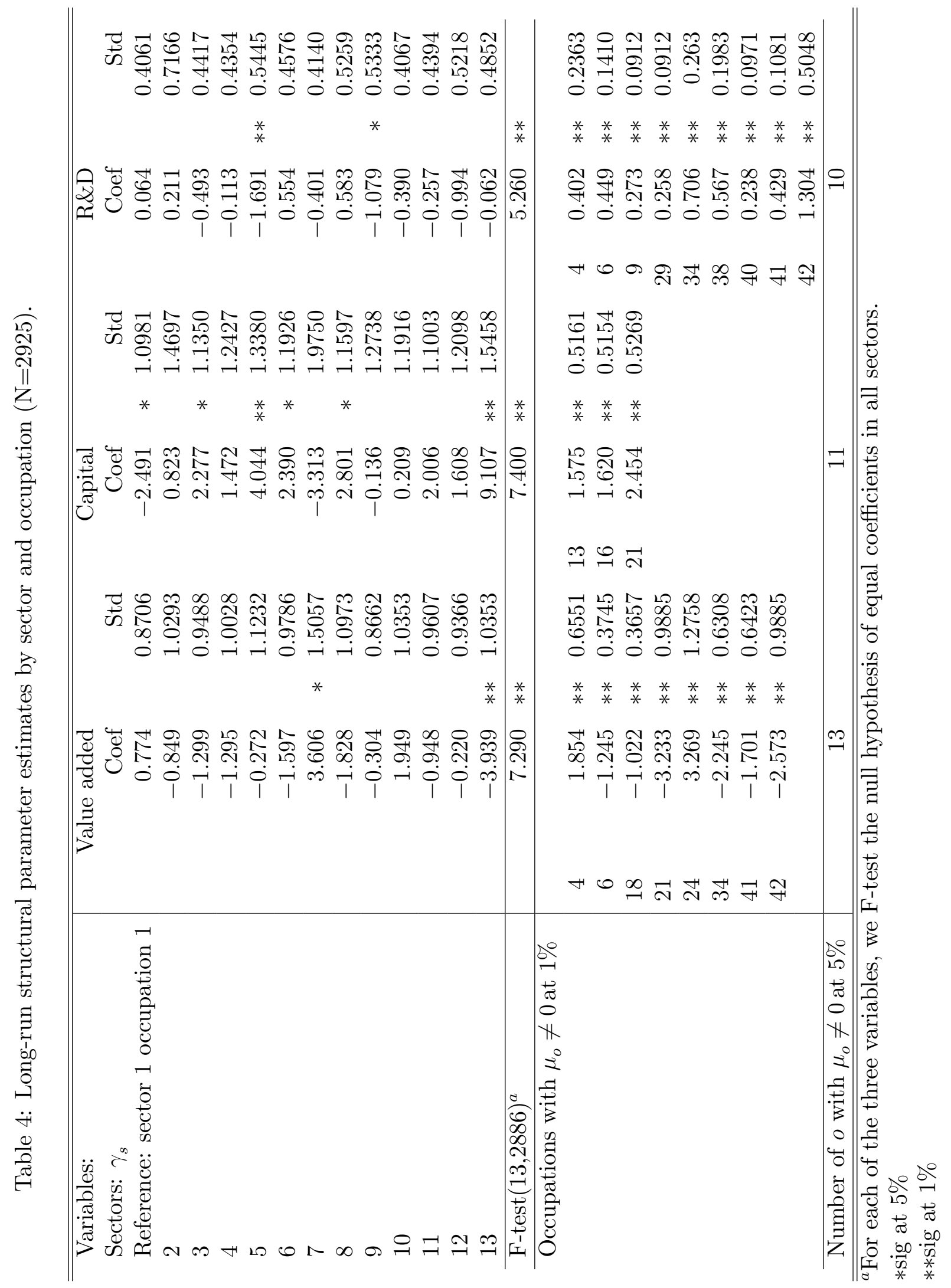




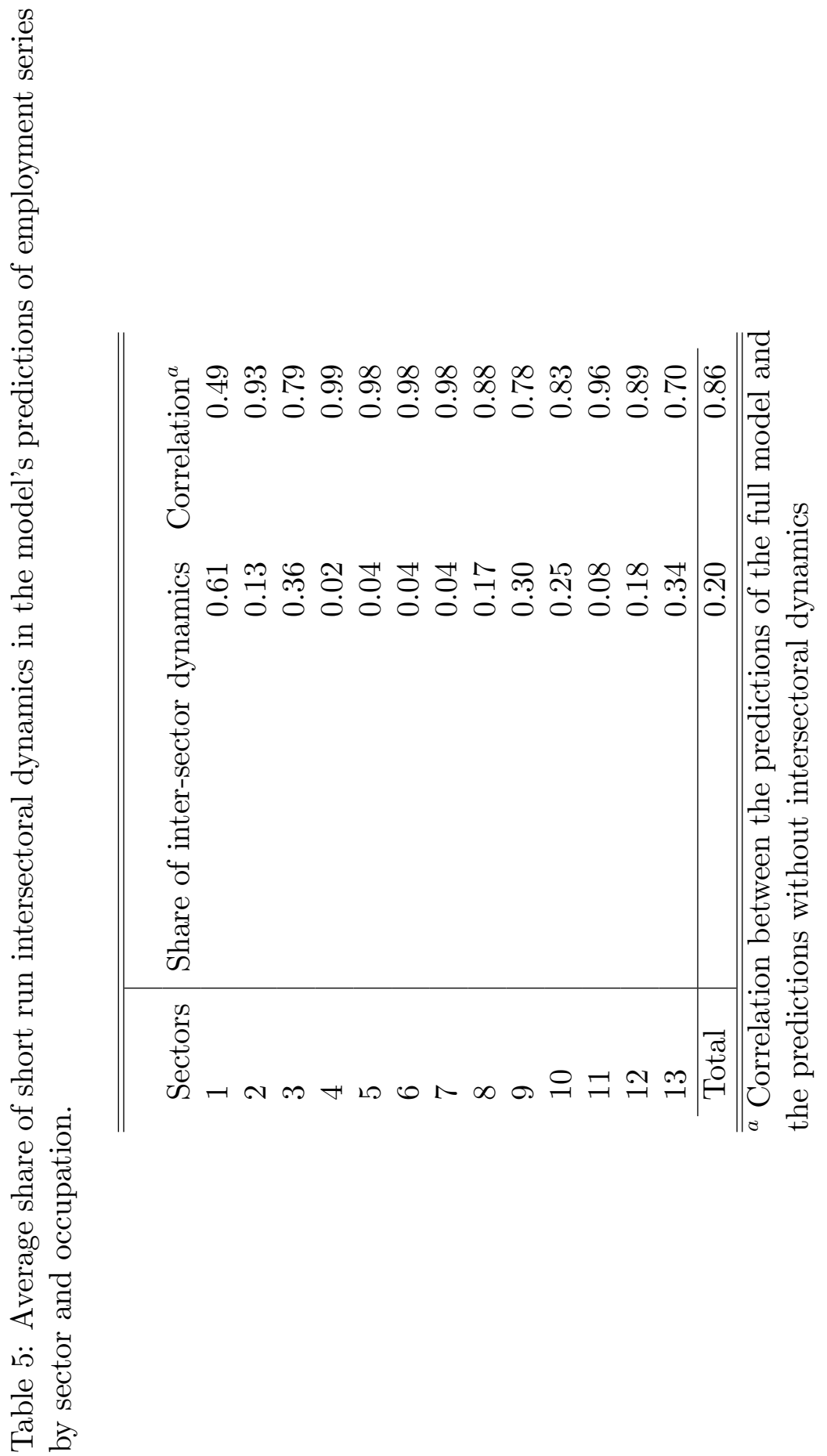




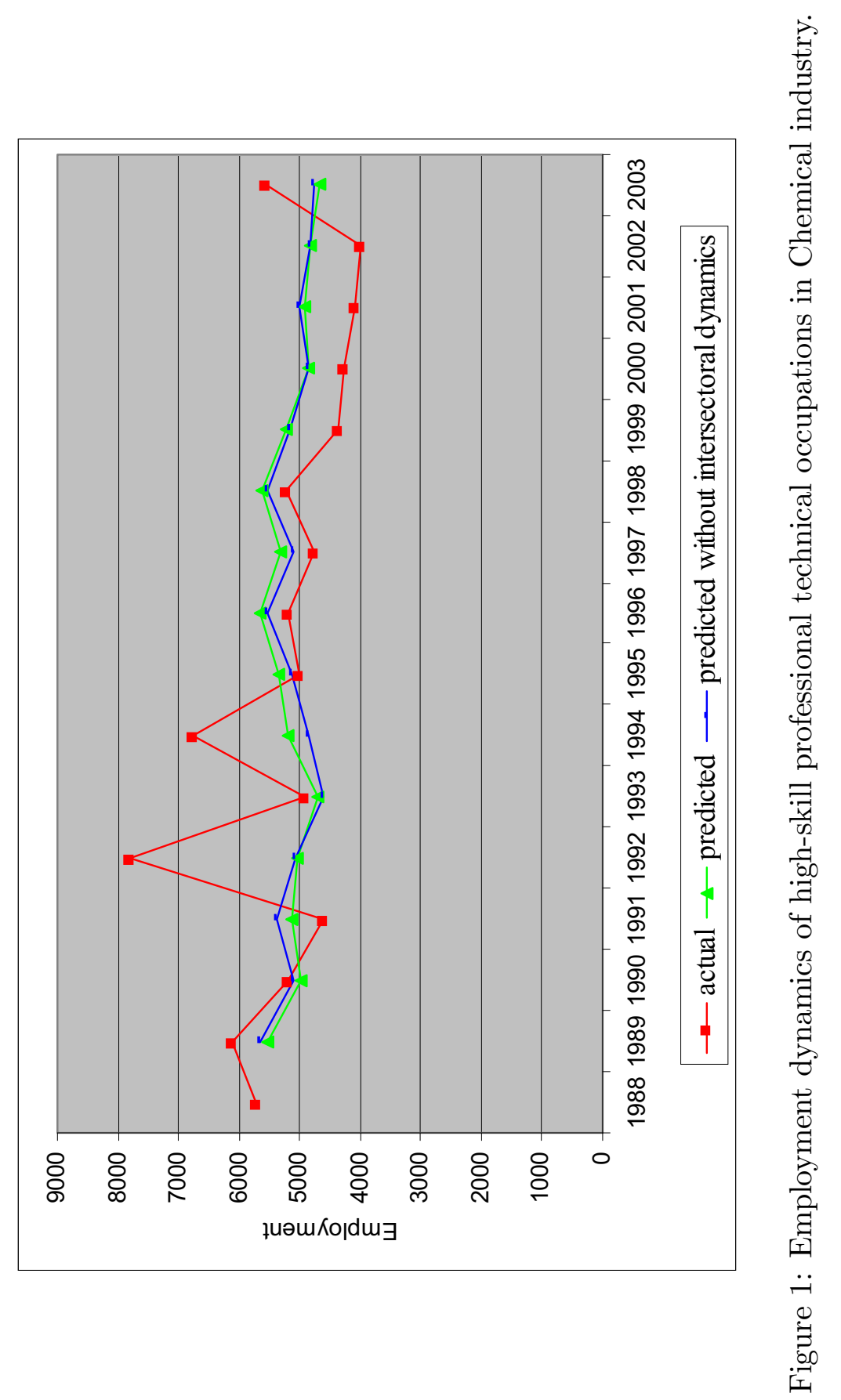




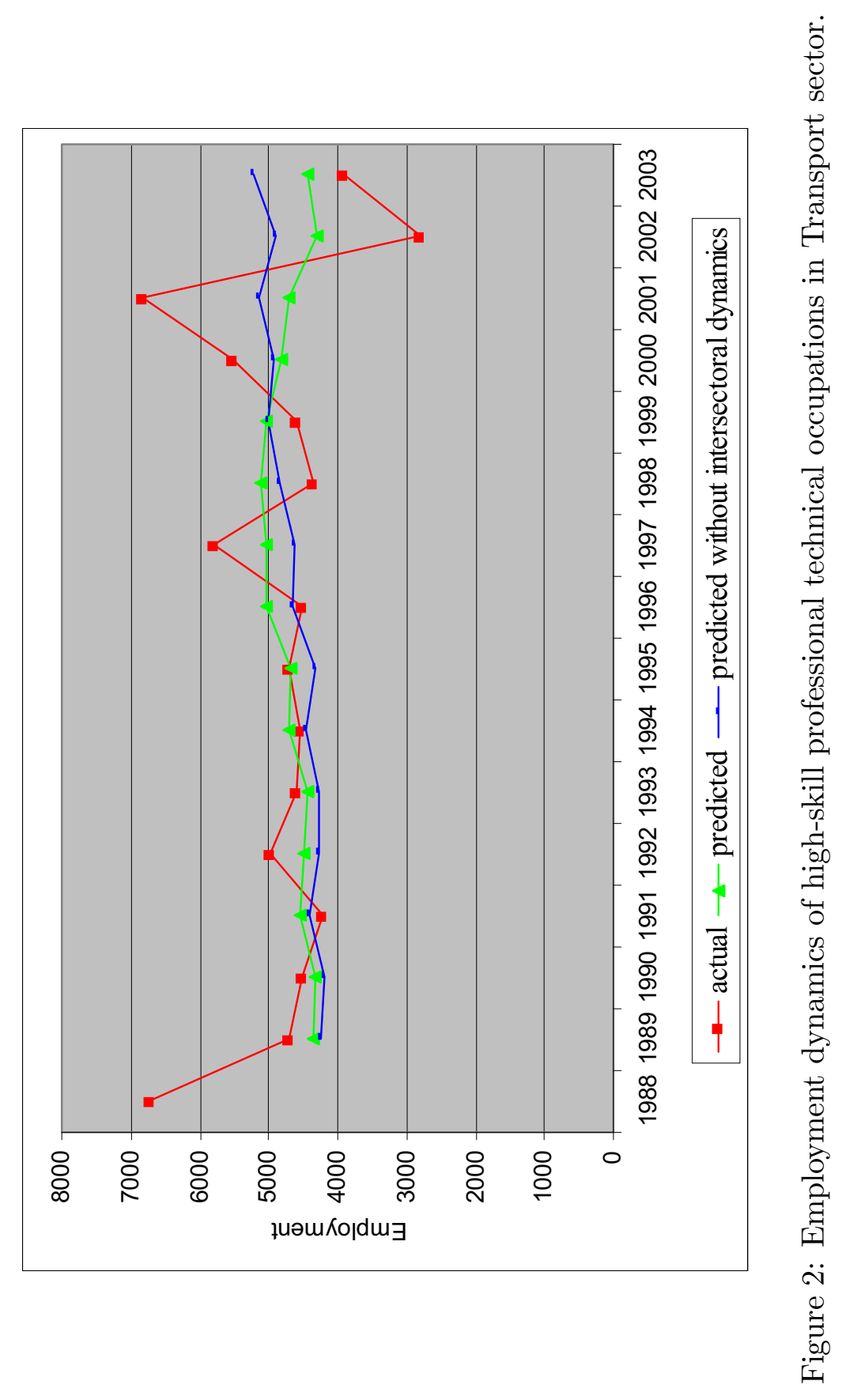




\section{Appendix}

Classification of sectors of industry

1 Agriculture

2 Food industry

3 Chemical

$4 \quad$ Metal industry and electronics

5 Paper, plastic, rubber and other industries

6 Energy

$7 \quad$ Building trade

8 Trade

9 Transport

10 Banking and insurance

11 Hotel and catering industry, commercial services

12 Health care and other public services

13 Governance and education

\section{Occupational classification}

1 Unskilled occupations

2-11 Low-skill occupations

2 General

3 Sports instructors

4 Agricultural

5 Mathematics and natural sciences

6 Technical

7 Transport

8 Medical and health-related

$9 \quad$ Clerical and commercial

10 Security

11 Home economics and service trades

12-22 Intermediate-skill occupations

12 Instructors in transport and sports

13 Agricultural

14 Mathematics and natural sciences

15 Technical

16 Transport

17 Medical and health-related

18 Clerical and commercial

19 Legal, public administration and security

20 Humanities, documentation and fine arts 
21 Social and behavioural

22 Home economics and service trades

23-34 High-skill professional occupations

23 Teachers and educationalists

24 Agricultural

25 Mathematics and natural sciences

26 Technical

27 Transport

28 Medical and health-related

29 Economic and commercial

30 Legal, public administration and security

31 Humanities, documentation and fine arts

32 Social and behavioural

33 Home economics

34 Managers

35-43 High-skill academic occupations

35 Teachers and educationalists

36 Agricultural

37 Mathematics and science

38 Technical

$39 \quad$ Medical and health-related

40 Economic and commercial

41 Legal, public administration and security

42 Humanities, social and behavioural

43 Managers 